\title{
Investigation of the Self-efficacy Beliefs of Pre-service Science Teachers in Terms of Following and Using the Innovations in the Field of Education
}

\author{
Hulya Dede ${ }^{1}$, Zeynel Abidin Yilmaz ${ }^{1}$, Nail Ilhan ${ }^{1}$ \\ ${ }^{1}$ Department of Science Education, Kilis 7 Aralık University, Kilis, Turkey \\ Correspondence: Nail Ilhan, Department of Science Education, Kilis 7 Aralık University, Kilis, Turkey.
}

Received: November 29, 2016

Accepted: December 7, 2016

Online Published: December 15, 2016

doi:10.11114/jets.v5i2.2025

URL: http://dx.doi.org/10.11114/jets.v5i2.2025

\begin{abstract}
One of the factors influencing teachers' and pre-service teachers' self-efficacy beliefs is the use of innovations and research in education (scientific articles, thesis, and new teaching materials). This study aims to examine to what extent pre-service science teachers follow the innovations in the field of education and use these innovations in their profession. Secondly, how the innovations in the field of education effect teachers' science teaching self-efficacy beliefs is examined. Survey method which is one of the quantitative research approaches was used in this study. The sample group of the study consisted of 563 pre-service science teachers enrolled in the Department of Science Teacher Training in the Faculty of Education at six universities in different regions of Turkey. The data in the study were collected using the "Science Teaching Efficacy Belief Instrument (STEBI)" developed by Riggs and Enochs (1990) and "Scale of Following and Using the Innovations in the Field of Education" (SFUIFE) developed by the researchers of this study. The data were analyzed both descriptively and predictively using SPSS. The results of the study showed that the primary resources (search engines such as google, web pages for course materials etc.) have been used and followed less than the secondary resources (conferences, symposiums, panels, workshops, thesis, and scientific articles etc.) by pre-service science teachers. In addition, it was found that following and using social media tools, thesis and scientific articles increase pre-service science teachers' self-efficacy beliefs of science teaching.
\end{abstract}

Keywords: self-efficacy beliefs, pre-service science teachers, science education research, innovations in education

\section{Introduction}

Throughout human history, human beings always have had the desire to understand the universe, to solve the secrets of the universe, on the one hand, and to control the nature and thus to have a more comfortable and secure life, on the other. As a result of systematic endeavors in line with this desire science came into existence (Yasar, 2006). The most important factor in the process of the existence of science is producing correct knowledge. Therefore, the process of producing knowledge is not a random process. Knowledge obtained from academic research by using scientific methods and standards is scientific information (Guclu \& Sotirofsji, 2006). The knowledge produced by scientific methods is important because it is correct and reliable (Korkmaz, Şahin \& Yeşil, 2011). The main features of scientific information are; it can be reached by logical reasoning; it deals with a certain subject area; it uses such methods as experiment and observation; it is systematic, organized, consistent, objective, verifiable and controllable (Cucen, 2001).

With the advance in science and technology in recently, our knowledge increases day by day. With the developing information and communication technologies information increases rapidly and it also becomes easier to access information. The new information society, fast communication and ever-changing technologies result in accepting knowledge as the main power and resource in all areas and in requiring it as a sine qua non in our lives (Calık \& Cinar, 2009). Before information is transferred on an electronic environment and internet people can access information via primary resources or printed resources and spend more time on accessing them. Today, with the use of internet and social media, both of which have a large share in our lives, as a resource to access information, people can access information with less effort and much faster. The increase in ways to access information and easy access to information increased the knowledge of people in the field of education as in other areas. The increase in correct and reliable information of individuals might pave the way for development for individuals in many aspects; success being the first one. However, mostly knowledge, skills and previous achievements could not be a good the indicator of future 
achievements. Besides, people's beliefs about their skills and the results of their efforts have a strong impact on their behaviors (Pajares, 1996). At this point, the term self-efficacy which is related to learning and academic performance emerges.

The term self-efficacy was first explained by Bandura. Bandura defined the term self-efficacy as one's belief in his/her capabilities to organize the courses of actions required to manage pre-service situations (Bandura, 1982). This belief determines how an individual thinks, feels, behaves and feels motivated (Bandura 1994). Self-efficacy is not a function of the skills of an individual, but a product, a result of the judgments of an individual on what s/he can do using his/her skills (Senemoglu, 2011). People with high self-efficacy feel more easy, confident and strong when they come up with a difficult task and event; people with low self-efficacy believe that events are more complicated than they really are, they have a narrow point of view and cannot solve the problems they encounter (Kahraman et al., 2013; Kaptan \& Korkmaz, 2002).

The self-efficacy belief regarding teaching science among teachers and pre-service teachers can be defined as their ideas about their skills to teach science effectively and efficiently. A large number of studies have been carried out on the self-efficacy beliefs of teachers and pre-service teachers recently; and in most of these studies the effect of some demographic characteristics (such as gender, the type of high school etc.) on self-efficacy were examined (Gercek et al., 2006; İlhan, Sözbilir, Şekerci, \& Yıldırım, 2015; Kahraman, Yılmaz, Bayrak \& Güneş, 2014; Ozdemir, 2008; Opera, 2008; Riggs, 1991; Saracaloglu \& Yenice, 2009; Topkaya, 2016). In addition, there are other studies in which the relationship between the self-efficacy beliefs of pre-service teachers towards teaching science and attitude (Morgil et al., 2004), success and learning styles (Denizoglu, 2008) are examined. In a study by Azar (2010) the level of the self-efficacy beliefs of teachers and pre-service teachers towards science teaching is examined. The results of the study revealed that in terms of gender and teaching experience, there were no significant difference between the teachers and pre-service teachers' self-efficacy beliefs and outcome expectations regarding teaching science and personal self-efficacy beliefs. When other studies on self-efficacy in the literature are examined, it is seen that there are also studies on perceived self-efficacy and academic self-efficacy (Adetoro, Simisaye \& Oyefuga, 2010; Niehaus, Rudasill \& Adelson, 2012). İlhan, Y1lmaz and Dede (2015) investigated that titudes of pre-service science teachers towards educational research and their science teaching efficacy beliefs in Turkey.

One of the factors effecting teachers' self-efficacy is their utilization of innovations and research (scientific articles, thesis, and newly developed teaching materials) in education. On the other hand, in research in which teachers' interest in such studies were examined, it was found that a great majority of teachers utilized the findings of researches to a very limited extent and that some teachers did not know much about the educational researches (Biesta, 2007; Cepni \& Kucuk, 2003; Costa, Marques, \& Kempa, 2000; Ekiz, 2006; Gore \& Gitlin, 2004; Shkedi, 1998; Yıldırım et al., 2014). The resources used by teachers who stated that they followed educational studies, are such resources as internet, television, newspapers, in-service trainings. It appears that teachers do not follow scientific publications (thesis, scientific articles etc.) a lot (Everton, Galton \& Pell, 2002; Yavuz, 2009; Yıldırım et al., 2014). A research by Dogan and Yilmaz (2012) showed that most of the teachers do not often use computer and computer software implementations. We think it is important that teachers use educational research to know how they will affect their self-efficacy beliefs. There are no studies on the relationship between teachers' and pre-service teachers' self-efficacy and following and utilizing of educational researches by them. Whereas, teachers' or pre-service teachers' awareness of educational researches or developments in education can be an important factor in increasing their self-efficacy.

The aim of this study is to investigate the level of pre-service science teachers' following and using the innovations in education and resources used in their following, and also how the level of pre-service science teachers' following and using the innovations in education effects on teachers' science teaching self-efficacy beliefs. In line with this aim; this study intends to answer the following research questions.

1. What is level of pre-service science teachers' following and using innovations in the field of education?

2. What is level of pre-service science teachers' science teaching efficacy belief?

3. Is there a relationship between pre-service science teachers' following and using innovations in the field of education and their science teaching efficacy belief?

\section{Method}

\subsection{Research Model}

Survey method, one of the quantitative research approaches, was used in this study. Survey method aims to describe a situation in present or in the past as it (Karasar, 2005). In this method, the researcher chooses a sample group among the target group and implements a questionnaire on this group and thus, collects data on relevant variables. Survey method is used to learn about people's attitudes, beliefs, values, demographics, behaviors, ideas, habits, wishes, and others 
(McMillan \& Schumacher, 2010).

\subsection{Research Participants}

The sample of this study composed of 563 pre-service science teachers enrolled in the Education Faculties at Ataturk University, Karadeniz Technical University, Erciyes University, Necmettin Erbakan University, Erzincan University and Marmara University. The distribution of the sample according to universities is presented in Table 1 . The study was implemented in spring semester in 2011/2012 academic year. One day a week, these pre-service science teachers worked as an intern within the scope of teaching practice and lectured in real classrooms under the supervision of practice teacher.

Table 1 . The distribution of sample according to universities

\begin{tabular}{ll}
\hline Universities & n \\
\hline Ataturk University & 129 \\
Karadeniz Technical University & 157 \\
Erciyes University & 62 \\
Necmettin Erbakan University & 108 \\
Erzincan University & 61 \\
Marmara University & 46 \\
\hline Total & $\mathbf{5 6 3}$ \\
\hline
\end{tabular}

\subsection{Data Collection Tools}

In the study, STEBI and SFUIFE were used. STEBI developed by Riggs and Enochs (1990) was adopted into Turkish by Bıkmaz (2004) and it is a five-point Likert type scale including 20 items. Reliability coefficient Cronbach Alpha of the scale was calculated to be 0.71. STEBI has two sub-dimensions that Personal Science Teaching Efficacy (PSTE) including 13 items and Science Teaching Outcome Expectancy (STOE) including 10 items.

In the SFUIFE, eight resource types (Radio, TV and newspapers; Course books intended for courses and exams in educational sciences; Scientific magazines; Thesis and scientific articles; Conferences, symposiums, panels and workshops; Web pages intended for course materials; Search engines such as google and yahoo; Social media tools (Youtube, Facebook, forum, blog etc.) are given in order to identify to what extent pre-service science teachers follow and use the innovations in the field of education. Pre-service teachers were asked to choose one of the three options for following and using the innovations in the field of education. These options were: I do not follow [NF], generally I follow [GF] and I follow and use in my profession [FUIP].

\subsection{Data Analysis}

The data were analyzed using SPSS (Social Sciences Statistical Package) statistics programme. Some of the data from the STEBI and the SFUIFE were analyzed descriptively and the results were given in percent and frequency table or in graphic. And some of the data were analyzed by inferential statistics.

\section{Findings}

In this section, the required analyses were made on the data obtained through data collection tools used in the study and the results were presented in table or graphic forms. The findings obtained were ordered by collecting them under the headings determined according to the research questions.

What is level of pre-service science teachers follow and use innovations in the field of education?

According to the data obtained from SFUIFE, among the eight resources that pre-service science teachers use to follow the innovations in the field of education, three of them were directly related to internet. The percentages and frequencies of these resources followed are calculated (Table 2).

When the pre-service science teachers' answers to the questions related to the following and using the innovations in education were examined, regarding the FUIP it was found that "search engines as google and yahoo" were the most frequently used tools $(59,9 \%)$ and they were followed by "course books intended for courses and exams in educational sciences" and "web pages intended for course materials" (47,2\%) with an equal share. However, the least used sources in the FUIP are "conferences, symposiums, panels and workshops" $(8,7 \%)$ and "thesis and scientific articles" $(9,9 \%)$. 
Table 2. The extent that pre-service science teachers follow and use the innovations in the field of education

\begin{tabular}{|c|c|c|c|c|c|c|c|}
\hline & & \multicolumn{2}{|l|}{ NF } & \multicolumn{2}{|l|}{ GF } & \multicolumn{2}{|c|}{ FUIP } \\
\hline & & n & $\%$ & $\mathbf{N}$ & $\%$ & & $\%$ \\
\hline \multicolumn{2}{|c|}{ Radio, TV and newspapers } & 86 & 15.3 & 365 & 64.8 & 106 & 18.8 \\
\hline \multicolumn{2}{|c|}{ Course books intended for courses and exams in educational sciences } & 52 & 9.2 & 242 & 43.0 & 266 & 47.2 \\
\hline \multicolumn{2}{|c|}{ Scientific magazines } & 143 & 25.4 & 291 & 51.7 & 125 & 22.2 \\
\hline \multicolumn{2}{|c|}{ Thesis and scientific articles } & 316 & 56.1 & 184 & 32.7 & 56 & 9.90 \\
\hline \multicolumn{2}{|c|}{ Conferences, symposiums, panels and workshops } & 309 & 54.9 & 194 & 34.5 & 49 & 8.70 \\
\hline & Web pages intended for course materials & 48 & 8.50 & 241 & 42.8 & 266 & 47.2 \\
\hline \multirow[t]{2}{*}{ Internet } & Search engines such as google and yahoo & 47 & 8.30 & 174 & 30.9 & 337 & 59.9 \\
\hline & Social media tools (Youtube, Facebook, forum, blog etc. ) & 99 & 17.6 & 170 & 30.2 & 105 & 18.7 \\
\hline
\end{tabular}

I do not follow (NF); Generally I follow (GF); I follow and use in my profession (FUIP).

When pre-service science teachers' answers were analyzed based on their "Generally I follow" option, it was found that "radio, TV and newspapers" rank in the first place with 64,8\%; followed by "scientific magazines" with 51,7\% and "course books intended for courses and exams in educational sciences" with 43\%. Again under the same item, the sources that pre-service science teachers generally follow at the lowest rate are found as "social media tools" with 30,2\% and "search engines such as google and yahoo" with 30,9\%.

When the answers of pre-service science teachers' answers were analyzed based on their "I do not follow" option, it was found that "thesis and scientific articles" rank in the first place with 56,1\% and followed by "conferences, symposiums, panels and workshops" respectively with 54,9\%. Again under this option, the least preferred sources are found as such "search engines as google and yahoo" with 8,3\% and "web pages intended for course materials" with 8,5\%.

When pre-service science teachers" answers to "Generally I follow" and "I follow and use in my profession" options are examined, it was found that although the rate of following some sources was high, their utilization in the profession had a low rate. The difference occurred in: "radio, TV and newspapers"; "scientific magazines"; "thesis and scientific articles"; "conference, symposium, panel and workshops" and "social media tools".

\section{What is level of pre-service science teachers' science teaching efficacy belief?}

STEBI has two sub-dimensions: "Personal Science Teaching Efficacy" (PSTE) and "Science Teaching Outcome Expectancy" (STOE). The data obtained from the STEBI were analyzed based on two sub-dimensions. In interpreting the data from the five-point Likert type scale, scale range is formed and the results are interpreted accordingly (Table 3).

Table 3. Ranges of STEBI and the sub-dimension

\begin{tabular}{ll}
\hline Mean Value & \\
\hline $1.00-1.80$ & Strongly Disagree \\
$1.81-2.60$ & Disagree \\
$2.61-3.40$ & Undecided \\
$3.41-4.20$ & Agree \\
$4.21-5.00$ & Strongly Agree \\
\hline
\end{tabular}

Arithmetic averages of each sub-dimension for the STEBI were calculated. When the averages of the sub-dimension of STEBI are analyzed separately, it is seen that the sub-dimension of STEBI "Personal Science Teaching Efficacy" $(\mathrm{M}=3.50)$ and "Science Teaching Outcome Expectancy" $(\mathrm{M}=3.45)$ are both at "I agree" level. When the general average of the STEBI $(\mathrm{M}=3.47)$ is analyzed, it is found to be at "I agree" level. Based on these results, it is possible to say that levels of science teaching efficacy belief are at a reasonably good.

Is there a relationship between pre-service science teachers'following and using innovations in the field of education and their science teaching efficacy belief?

The average values of science teaching efficacy belief of pre-service science teachers were calculated according to their NF, GF and FUIP statuses in the field of education (Table 4). When the science teaching efficacy belief averages of pre-service science teachers who chose "I do not follow" option is examined, the highest self-efficacy beliefs are "thesis and scientific articles" $(\mathrm{M}=3.46)$ and "conference, symposium, panel and workshops" $(\mathrm{M}=3.44)$. The lowest self-efficacy belief average is "web pages intended for course materials" $(\mathrm{M}=3.27)$ and "course books intended for courses and exams in educational sciences" $(\mathrm{M}=3.33)$. When the science teaching efficacy belief averages of pre-service science teachers who chose "generally I follow" option is examined, the highest average for self-efficacy belief is "conference, symposium, panel and workshops" $(\mathrm{M}=3.52)$ and "thesis and scientific articles" $(\mathrm{M}=3.50)$ respectively. The lowest self-efficacy belief average is such "search engines as google and yahoo" $(\mathrm{M}=3.37)$ and "web pages intended for course materials” ( $\mathrm{M}=3.43)$ respectively.

Finally, when the source types used and the averages of science teaching self-efficacy beliefs for those pre-service science teachers choosing the option "I follow and use in my profession" are analyzed, the highest self-efficacy belief is 
"social media tools (Youtube, Facebook, forums, blogs etc.)" ( $(\mathrm{M}=3.61)$ and "thesis and scientific articles" (M=3.59), respectively. The lowest self-efficacy belief average is "course books intended for courses and exams in educational sciences" $(\mathrm{M}=3.54)$ and "search engines as google and yahoo" $(\mathrm{M}=3.55)$.

Table 4. Science teaching efficacy belief according to their NF, GF and FUIP statuses in the field of education

\begin{tabular}{lllll}
\hline & & n & Mean & Std.Deviatioan \\
\hline \multirow{2}{*}{ Radio, TV and newspapers } & NF & 86 & 3.34 & .43 \\
& GF & 365 & 3.48 & .38 \\
Course books intended for courses and exams in educational sciences & FF & 52 & 3.33 & .36 \\
& FF & 242 & 3.46 & .38 \\
Scientific magazines & FUIP 266 & 3.54 & .40 \\
& NF & 143 & 3.39 & .42 \\
& GF & 291 & 3.49 & .36 \\
Thesis and scientific articles & FUIP 125 & 3.56 & .42 \\
& NF & 316 & 3.46 & .39 \\
& GF & 184 & 3.50 & .38 \\
Conferences, symposiums, panels and workshops & FUIP 56 & 3.59 & .45 \\
& NF & 309 & 3.44 & .40 \\
Web pages intended for course materials & GF & 194 & 3.52 & .37 \\
& FUIP 49 & 3.57 & .42 \\
Search engines such as google and yahoo & NF & 48 & 3.27 & .37 \\
& GF & 241 & 3.43 & .36 \\
Social media tools (Youtube, Facebook, forum, blog etc.) & FUIP 266 & 3.57 & .40 \\
& NF & 47 & 3.41 & .37 \\
& GF & 174 & 3.37 & .39 \\
\hline
\end{tabular}

I do not follow (NF); Generally I follow (GF); I follow and use in my profession (FUIP).

When Table 4 is examined and the self-efficacy beliefs' arithmetic averages are compared to each other in terms of NF, GF and FUIP in each source, it is seen that in all sources FUIP groups' self-efficacy arithmetic averages are higher than others. It seem that pre-service science teachers' who follow and use the innovations related to educational researches have higher self-efficacy beliefs than teachers who less frequently follow or do not follow innovations. The difference between "science teaching self-efficacy beliefs" of pre-service science teachers by the resource types they follow and use in their profession is examined using the one-way analysis of variance (ANOVA) (Table 5). The results of ANOVA showed that there is no significant difference among "science teaching self-efficacy beliefs" by the source types of pre-service science teachers' follow and use in their profession $(F(7,1302)=0.511 ; \mathrm{p}>0.01)$

Table 5. ANOVA results for self-efficacy belief

\begin{tabular}{|c|c|c|c|c|c|c|}
\hline & $\begin{array}{l}\text { Science Teaching Self-Efficacy } \\
\text { Beliefs }\end{array}$ & Sum of Squares & Degree of Freedom(DF) & Mean Square & $\mathbf{F}$ & Sig. (p) \\
\hline \multirow{3}{*}{$\begin{array}{l}\text { FUIP by the source } \\
\text { types }\end{array}$} & Between Groups & 0.588 & 7 & 0.084 & 0.511 & \multirow{3}{*}{0.827} \\
\hline & Within Groups & 214,071 & 1302 & 0.164 & & \\
\hline & Total & 214,659 & 1309 & & & \\
\hline
\end{tabular}

ANOVA was carried out to determine whether there were statistically significant differences between pre-service science teachers' science teaching self-efficacy belief by the their NF, GF and FUIP status according to the source type used in following educational researches by them (Table 6).

According to ANOVA analysis, there were statistically significant differences $(\mathrm{p}<0.05)$ between pre-service science teachers' science teaching self-efficacy belief by their NF, GF and FUIP status for the source type (except "thesis and scientific articles", and "Conferences, symposiums, panels and workshops" source) used in following educational researches by pre-service science teacher (Table 6). 
Table 6. ANOVA results for NF, GF and FUIP

\begin{tabular}{|c|c|c|c|c|c|c|}
\hline & $\begin{array}{l}\text { Science Teaching Self-Efficacy } \\
\text { Beliefs }\end{array}$ & $\begin{array}{ll}\text { Sum of } \\
\text { Squares }\end{array}$ & DF & $\begin{array}{l}\text { Mean } \\
\text { Square }\end{array}$ & $\mathbf{F}$ & $\begin{array}{l}\text { Sig. } \\
(p)\end{array}$ \\
\hline \multirow{3}{*}{ Radio, TV and newspapers } & Between Groups & 2.427 & 2 & 1.213 & 8.025 & \multirow{3}{*}{$.000 *$} \\
\hline & Within Groups & 83.766 & 554 & .151 & & \\
\hline & Total & 86.193 & 556 & & & \\
\hline \multirow{3}{*}{$\begin{array}{l}\text { Course books intended for courses and exams in } \\
\text { educational sciences }\end{array}$} & Between Groups & 2.164 & 2 & 1.082 & 7.169 & \multirow{3}{*}{$.001 *$} \\
\hline & Within Groups & 84.069 & 557 & .151 & & \\
\hline & Total & 86.234 & 559 & & & \\
\hline \multirow{3}{*}{ Scientific magazines } & Between Groups & 2.024 & 2 & 1,012 & 6.675 & \multirow{3}{*}{$.001 *$} \\
\hline & Within Groups & 84.287 & 556 & .152 & & \\
\hline & Total & 86.311 & 558 & & & \\
\hline \multirow{3}{*}{ Thesis and scientific articles } & Between Groups & .870 & 2 & .435 & 2.833 & \multirow{3}{*}{.060} \\
\hline & Within Groups & 84.928 & 553 & .154 & & \\
\hline & Total & 85.798 & 555 & & & \\
\hline \multirow{3}{*}{ Conferences, symposiums, panels and workshops } & Between Groups & 1.158 & 2 & .579 & 3.778 & \multirow{3}{*}{$.023 *$} \\
\hline & Within Groups & 84.128 & 549 & .153 & & \\
\hline & Total & 85.285 & 551 & & & \\
\hline \multirow{3}{*}{ Web pages intended for course materials } & Between Groups & 5,169 & 2 & 2.585 & 17.682 & \multirow{3}{*}{$.000 *$} \\
\hline & Within Groups & 80.685 & 552 & .146 & & \\
\hline & Total & 85.855 & 554 & & & \\
\hline \multirow{3}{*}{ Search engines such as google and yahoo } & Between Groups & 3.827 & 2 & 1.913 & 12.863 & \multirow{3}{*}{$.000 *$} \\
\hline & Within Groups & 82.555 & 555 & .149 & & \\
\hline & Total & 86.381 & 557 & & & \\
\hline \multirow{3}{*}{$\begin{array}{l}\text { Social media tools (Youtube, Facebook, forum, blog } \\
\text { etc.) }\end{array}$} & Between Groups & 3.882 & 2 & 1.941 & 12.058 & \multirow{3}{*}{$.000 *$} \\
\hline & Within Groups & 59.719 & 371 & .161 & & \\
\hline & Total & 63.601 & 373 & & & \\
\hline
\end{tabular}

$* p<0.05$

In order to determine the difference between the groups (NF, GF and FUIP for the source type), post-hoc multiple comparisons tests were made by use of the least square difference (LSD), (Table7).

When Table 7 is examined;

- Results of Table 7 suggest that there are statistically significant difference between "science teaching self-efficacy beliefs" of pre-service science teachers who do not follow (NF) (M=3.34, SD=.43) and generally follow (GF) (M=3.48, $\mathrm{SD}=.38)$ and follow and use in their profession (FUIP) $(\mathrm{M}=3.57, \mathrm{SD}=.40)$ according to "radio, TV and newspapers"

- Results of Table 7 suggest that there are statistically significant difference between "science teaching self-efficacy beliefs" of pre-service science teachers who the $\mathrm{NF}(\mathrm{M}=3.33, \mathrm{SD}=.36)$ and $\mathrm{GF}(\mathrm{M}=3.46, \mathrm{SD}=.38)$ and $\mathrm{FUIP}(\mathrm{M}=3.54$, $\mathrm{SD}=.40$ ) according to "Course books intended for courses and exams in educational sciences"

- Results of Table 7 suggest that there are statistically significant difference between "science teaching self-efficacy beliefs" of pre-service science teachers who the NF (M=3.27, $\mathrm{SD}=.37)$ and $\mathrm{GF}(\mathrm{M}=3.43, \mathrm{SD}=.36)$ and FUIP (M=3.57, $\mathrm{SD}=.40$ ) according to "Web pages intended for course materials"

- Results of Table 7 suggest that there are statistically significant difference between "science teaching self-efficacy beliefs" of pre-service science teachers who the $\mathrm{NF}(\mathrm{M}=3.34, \mathrm{SD}=.39)$ and $\mathrm{GF}(\mathrm{M}=3.48, \mathrm{SD}=.39)$ and $\mathrm{FUIP}(\mathrm{M}=3.61$, $\mathrm{SD}=.44$ ) according to "Social media tools (Youtube, Facebook, forum, blog etc.)"

When the results of the analysis is examined, it is seen that there is a statistically significant difference in support of FUIP among NF, GF and FUIP options in "scientific magazines" and "conferences, symposiums, panels and workshops"; and a statistically significant difference in support of FUIP among NF, GF and FUIP options in terms of self-efficacy belief averages (Table 7).

There is a statistically significant difference found in support of the FUIP $(\mathrm{M}=3.55, \mathrm{SD}=.39)$ pre-service teachers $(\mathrm{p}<.05)$ among self-efficacy belief averages among pre-service science teachers who the NF $(M=3.41, S D=.37)$ in terms of "Search engines such as google and yahoo".; and a statistically significant difference found in support of FUIP teachers $(\mathrm{p}<.05)$ among self-efficacy belief averages among pre-service science teachers who GF $(\mathrm{M}=3.37, \mathrm{SD}=.39)$ in terms of "Search engines such as google and yahoo". 
Table 7. LSD post hoc tests for differences among the groups

\begin{tabular}{|c|c|c|c|c|c|}
\hline & & & Mean Difference (I-J) & Std. Error & Sig. \\
\hline \multirow{6}{*}{ Radio, TV and newspapers } & \multirow{2}{*}{ NF } & GF & $-.14003(*)$ & .04661 & .003 \\
\hline & & FUIP & $-.22457(*)$ & .05643 & .000 \\
\hline & \multirow{2}{*}{ GF } & $\mathrm{NF}$ & $.14003(*)$ & .04661 & .003 \\
\hline & & FUIP & $-.08455(*)$ & .04290 & .049 \\
\hline & \multirow{2}{*}{ FUIP } & $\mathrm{NF}$ & $.22457(*)$ & .05643 & .000 \\
\hline & & GF & $.08455(*)$ & .04290 & .049 \\
\hline \multirow{6}{*}{$\begin{array}{l}\text { Course books intended for courses and exams in educational } \\
\text { sciences }\end{array}$} & \multirow{2}{*}{ NF } & GF & $-.12653(*)$ & .05938 & .034 \\
\hline & & FUIP & $-.20706(*)$ & .05891 & .000 \\
\hline & \multirow{2}{*}{ GF } & $\mathrm{NF}$ & $.12653(*)$ & .05938 & .034 \\
\hline & & FUIP & $-.08053(*)$ & .03451 & .020 \\
\hline & \multirow{2}{*}{ FUIP } & $\mathrm{NF}$ & $.20706(*)$ & .05891 & .000 \\
\hline & & GF & $.08053(*)$ & .03451 & .020 \\
\hline \multirow{6}{*}{ Scientific magazines } & \multirow{2}{*}{$\mathrm{NF}$} & GF & $-.10521(*)$ & .03976 & .008 \\
\hline & & FUIP & $-.17014(*)$ & .04767 & .000 \\
\hline & \multirow{2}{*}{ GF } & $\mathrm{NF}$ & $.10521(*)$ & .03976 & .008 \\
\hline & & FUIP & -.06493 & .04164 & .119 \\
\hline & \multirow{2}{*}{ FUIP } & $\mathrm{NF}$ & $.17014(*)$ & .04767 & .000 \\
\hline & & GF & .06493 & .04164 & .119 \\
\hline \multirow{6}{*}{ Conferences, symposiums, panels and workshops } & \multirow{2}{*}{$\mathrm{NF}$} & GF & $-.07827(*)$ & .03586 & .029 \\
\hline & & FUIP & $-.12808(*)$ & .06019 & .034 \\
\hline & \multirow{2}{*}{ GF } & $\mathrm{NF}$ & $.07827(*)$ & .03586 & .029 \\
\hline & & FUIP & -.04981 & .06259 & .426 \\
\hline & \multirow{2}{*}{ FUIP } & $\mathrm{NF}$ & $.12808(*)$ & .06019 & .034 \\
\hline & & GF & .04981 & .06259 & .426 \\
\hline \multirow{6}{*}{ Web pages intended for course materials } & \multirow{2}{*}{ NF } & GF & $-.16093(*)$ & .06043 & .008 \\
\hline & & FUIP & $-.30693(*)$ & .05996 & .000 \\
\hline & \multirow{2}{*}{ GF } & $\mathrm{NF}$ & $.16093(*)$ & .06043 & .008 \\
\hline & & FUIP & $-.14600(*)$ & .03400 & .000 \\
\hline & \multirow{2}{*}{ FUIP } & TE & $.30693(*)$ & .05996 & .000 \\
\hline & & GF & $.14600(*)$ & .03400 & .000 \\
\hline \multirow{6}{*}{ Search engines such as google and yahoo } & \multirow{2}{*}{ NF } & GF & .03446 & .06340 & .587 \\
\hline & & FUIP & $-.14122(*)$ & .06005 & .019 \\
\hline & \multirow{2}{*}{ GF } & $\mathrm{NF}$ & -.03446 & .06340 & .587 \\
\hline & & FUIP & $-.17568(*)$ & .03600 & .000 \\
\hline & \multirow{2}{*}{ FUIP } & TE & $.14122(*)$ & .06005 & .019 \\
\hline & & GF & $.17568(*)$ & .03600 & .000 \\
\hline \multirow{6}{*}{ Social media tools (Youtube, Facebook, forum, blog etc.) } & $\mathrm{NF}$ & GF & $-.13821(*)$ & .05072 & .007 \\
\hline & & FUIP & $-.27596(*)$ & .05620 & .000 \\
\hline & GF & $\mathrm{NF}$ & $.13821\left(^{*}\right)$ & .05072 & .007 \\
\hline & $\mathrm{GF}$ & FUIP & $-.13775(*)$ & .04980 & .006 \\
\hline & FUUP & $\mathrm{NF}$ & $.27596(*)$ & .05620 & .000 \\
\hline & FUIP & GF & $.13775(*)$ & .04980 & .006 \\
\hline
\end{tabular}

*The mean difference is significant at the .05 level.

I do not follow (NF); Generally I follow (GF); I follow and use in my profession (FUIP).

\section{Conclusion and Discussion}

This study was carried out on pre-service science teachers who worked as an intern within the scope of teaching practice and lectured in real classrooms under the supervision of practice teacher. The level of pre-service science teachers' following and using the innovations in education and resources used in their following was investigated. Also how the level of pre-service science teachers' following and using the innovations in education effects on teachers' science teaching self-efficacy beliefs was examined.

According to the findings obtained by SFUIFE; the most frequently used sources in following and using the innovations in education by teachers are; "search engines as google and yahoo" (59,9\%) and "web pages intended for course materials" (59,9\%). And the least used sources in this field are "conferences, symposiums, panels and workshops" $(8,7 \%)$ and "thesis and scientific articles" $(9,9 \%)$. The least used sources by pre-service science teachers in following and using the innovations in education are the primary sources. In the literature, primary sources are known as sources that incorporate valid scientific and technical information (McMillan \& Schumacher, 2010). Because the information in primary sources is produced using scientific methods, they are important in terms of their accuracy and reliability (Korkmaz et al., 2011). Because the rate of fault in information and findings in primary sources is low, pre-service science teachers can be suggested to use these primary sources more. However, according to the findings obtained by 
SFUIFE, it was found that pre-service science teachers did not use primary sources in following and using the innovations in education. As a result, it was found that the most frequently used sources by pre-service science teachers in following and using the innovations in education are secondary resources (search engines such as google and yahoo). Similar findings were obtained from other studies in the literature carried out on teachers (Everton, 2002; Yavuz, 2009; Yıldırım et al., 2014; İlhan, Sözbilir, Şekerci, \& Yıldırım, 2015).

Although the level of following the innovations in education were high among teachers, the level of using them in their profession were low. It is also seen that pre-service science teachers follow "conferences, symposiums, panels and workshops" and "thesis and scientific articles", which need more knowledge and effort, less. The reason behind could be that the teachers do not know which sources have which kind of information, or they do not know how to access and use this information. Similar issues are discussed in the literature (Biesta, 2007; De Jong, 2004; Yıldırım et al., 2014).

In the present study, in order to answers to research questions (How does pre-service science teachers' following and using innovations in the field of education affect their science teaching efficacy belief?) the data obtained from SFUIFE and STEBI are compared. It is revealed that averages of pre-service science teachers' science teaching efficacy belief changes according to level of their follow and use innovations in the field of education. Also, it is concluded that as the rate of their following and using the sources increases, their science teaching efficacy belief increases, too. When the effective sources in high self-efficacy beliefs of pre-service science teachers are examined, according to the self-efficacy belief averages of those pre-service science teachers who chose I follow and use in my profession (FUIP); the highest self-efficacy belief are found in "social media tools" (Youtube, Facebook, forum, blog etc." (M=3.61) and "thesis and scientific articles" $(M=3.59)$. And the lowest self-efficacy belief are found in "course books intended for courses and exams in educational sciences $(\mathrm{M}=3.54)$ and "such search engines as google, yahoo etc." $(M=3.55)$. Based on these results, it is possible to say that following and using "social media tools" and "thesis and scientific articles" increase pre-service science teacher's self-efficacy beliefs.

Teachers' following the educational research and utilizing them in classes should be emphasized as one of the acquisitions to be formed in the process of educating teachers. In this respect, it can be suggested that in the light of the results obtained from this study, some arrangements in the courses and their contents in the institutions where teachers are educated can be made; and pre-service science teachers can be provided with more information about which sources have which kind of information; how to access these sources and how they can use these information in their profession.

Teachers' science teaching efficacy belief is important for effectively and efficiently teaching (Allinder, 1995; Ross, 1994). It is said that teachers' self-efficacy beliefs are established and improved in the teacher education program when they are pre-service teachers (Kucukyllmaz \& Duban, 2006). In a study by Azar (2010), there is no significant difference between pre-service science teachers and teachers in their self-efficacy beliefs. This means pre-service science teachers self-efficacy beliefs do not change after graduation. In addition, pre-service science teachers use educational sources for improving their teaching. According to the results of this study, it is mostly such sources as social communication tools, thesis and articles that effect the increase of pre-service science teachers self-efficacy beliefs and thus, it is necessary to include more courses and activities in university educational programs to help them use these sources more and easily.

The findings obtained from this study show the level of pre-service science teachers' following and using the innovations in education effects on teachers' science teaching self-efficacy beliefs. It is also, further research can be done for in-service teachers.

\section{Acknowledgements}

The authors would like to thank the Scientific Research Projects Unit of Kilis 7 Aralık University for financial support (Project number: 2012/1/MAP08)

\section{References}

Adetoro, N., Simisaye, A. O., \& Oyefuga, A. B. (2010). Relationship between perceived self-efficacy and information literacy among library and information science undergraduates in a Nigerian university of education. Ife Psycholog IA, 18(2), 172-191. https://doi.org/10.4314/ifep.v18i2.56758

Allinder, R. M. (1995). An examination of the relationship between teacher efficacy and curriculum based measurement and student achievement. Remedial and Special Education, 27, 141-152. https://doi.org/10.1177/074193259501600408

Azar, A. (2010). In-service and pre-service secondary science teachers' self-efficacy beliefs about science teaching. Educational Research and Reviews, 5(4) 175-188. http://dx.doi.org/10.5897/ERR09.243 
Bandura, A. (1982). Self-efficacy mechanism in human agency. American Psychologist, 37(2), 122-147. https://doi.org/10.1037/0003-066X.37.2.122

Bandura, A. (1994). Self-efficacy. V. S. Ramachaudran (Ed.), In Encyclopedia of human behavior (p. 71-81). New York: Academic Press.

Biesta, G. (2007). Bridging the gap between educational research and educational practice: The need for critical distance. Educational Research and Evaluation, 13(3), 295-301. https://doi.org/10.1080/13803610701640227

Bikmaz, H. F. (2004). The validity and reliability study of the elementary school teachers' science teaching self-efficacy beliefs scale. National Education Journal, 31(161), 172-180.

Calık, D., \& Cinar, O. P. (2009, December). From past to present approaches to knowledge information society and internet. Paper presented at the 14th. Internet Congress in Turkey, İstanbul, Turkey.

Cepni, S., \& Kucuk, M. (2003). Science teacher education research of the determination of impact on applications: A case study. Eurasian Journal of Educational Research, 4(2), 75-84.

Costa, N., Marques, L., \& Kempa, R. (2000). Science teachers' awareness of findings from education research. Research in Science and Technological Education, 18, 37-44. http://dx.doi.org/10.1080/713694955

Cucen, K. A. (2001). Epistemology. Bursa: Asa Bookstore.

De Jong, O. (2004). Mind your step: Bridging the research-practice gap. Australian Journal of Education in Chemistry, $64,5-9$.

Denizoglu, P. (2008). The assessment of the relation between self-efficacy belief levels, learning styles of science teacher candidates towards science teaching and their attitudes towards science (Unpublished Master Thesis). Cukurova University Social Science Institute, Adana, Turkey

Doğan, Y., \& Yilmaz, M. (2012). Investigation of the using instructional technology in science and technology course. Adlyaman Üniversitesi Fen Bilimleri Dergisi, 2(2), 107-121.

Ekiz, D. (2006). Primary school teachers' attitudes towards educational research. Educational sciences: Theory and Practice, 6(2), 373-402.

Everton, T., Galton, M., \& Pell, T. (2002). Educational research and the teacher. Research Papers in Education, 17(4), 373-401. http://dx.doi.org/10.1080/0267152022000031388

Gercek, C., Yilmaz, M., Koseoglu, P., \& Soran, H. (2006). Biology teaching self-efficacy beliefs of the teacher candidates, Ankara University Journal of Faculty of Educational Sciences, 39(1), 57-73.

Gore, J. M., \& Gitlin, A. D. (2004). [Re]Visioning the academic-teacher divide: power and knowledge in the educational community. Teachers and Teaching: theory and practice, 10(1), 35-58. https://doi.org/10.1080/13540600320000170918

Guclu, N., \& Sotirofski, K. (2006). Knowledge management, Turk Journal of Educational Sciences, 4(4), 351-371.

İlhan, N., Sözbilir, M., Şekerci, A. R., \& Yıldırım, A. (2015). Turkish science teachers' use of educational research and resources. Eurasia Journal of Mathematics, Science \& Technology Education, 11(6), 1231-1248. doi: 10.12973/eurasia.2015.1374a

İlhan, N., Y1lmaz, Z. A., \& Dede, H. (2015). Attitudes of pre-service science teachers towards educational research and their science teaching efficacy beliefs in Turkey. Journal of Baltic Science Education, 14(2), 183-193.

Kahraman, S., Yılmaz, Z. A., Bayrak, R., \& Günes, K. (2014). Investigation of pre-service science teachers' self-efficacy beliefs of science teaching. Social and Behavioral Sciences Journal, 136, 501-505. https://doi.org/10.1016/j.sbspro.2014.05.364

Kahraman, S., Yılmaz, Z. A., Erkol, M., \& Yalçın, S. A. (2013). Investigation of pre-service teachers' self-efficacy beliefs of educational internet use. Elementary Education Online, 12(4), 1000-1015.

Kaptan, F., \& Korkmaz, H. (2002, November). Effectiveness of problem-based learning approach on development of problem solving and self-efficacy beliefs levels in science education. Paper presented at the 5th Science and Matematic Education Congress, Ankara, Turkey.

Karasar, N. (2005). Scientific research method. Ankara: Nobel Publication Distribution

Korkmaz, Ö., Şahin, A., \& Yeşil, R. (2011a). Study of validity and reliability of scale of attitude towards scientific research. İlkögretim Online, 10(3), 961-973. http://ilkogretim-online.org.tr 
Kucukyılmaz, E. A., \& Duban, N. (2006). The opinions of primary teacher candidates on taking measures to increase science teaching self-efficacy. Journal of Yuzuncu Yll Education Faculty, 3(2), 1-23.

McMillan, J. H., \& Schumacher, S. (2010). Research in education: Evidence-based inquiry (7th Edition). Boston: Pearson Education.

Morgil, I., Secken, N., \& Yucel, A. S. (2004). Based on some investigation of self-efficacy beliefs of preservice chemistry teachers variables. Journal of Ballkesir University Graduate School of Nature and Applied Sciences, $6(1), 62-72$.

Niehaus, K., Rudasill, K. M., \& Adelson, J. L. (2012). Self-efficacy, intrinsic motivation, and academic outcomes among latino middle school students participating in an after-school program. Hispanic Journal of Behavioral Science, 34(1), 118-136. https://doi.org/10.1177/0739986311424275

Opare, J. O. (2008). Gender differences in academic self-efficacy beliefs and perception of the internal dynamics of the collaborative learning context. Gender and Behaviour, 1(6), 1617-1631. https://doi.org/10.4314/gab.v6i1.23408

Ozdemir, S. M. (2008). An investigation of prospective primary teachers' self-efficacy beliefs regarding teaching process in terms of certain variables. Educational Administration: Theory and Practice, 54, 277-306.

Pajares, F. (1996). Self-efficacy beliefs in akademic settings. Rewiew of Educational Research, 66(4), 543-578. https://doi.org/10.3102/00346543066004543

Riggs, I. M. (1991, April). Gender differences in elemantary science teacher. Paper presented at the Self-Efficacy American Edvantional Research Association, Chicago, USA.

Riggs, I. M., \& Enochs, L. G. (1990). Toward the development of an elementary teacher's science teaching efficacy belief instrument. Science Education, 74(6), 625-637. https://doi.org/10.1002/sce.3730740605

Ross, J. A. (1994). The impact of an inservice to promote cooperative learning on the stability of teacher efficacy. Teaching and Teacher Education, 10, 381-394, 1994. https://doi.org/10.1016/0742-051x(94)90020-5

Saracaloglu, A. S., \& Yenice, N. (2009). Investigating the self-efficacy beliefs of science and elementary teachers with respect to some variables. Journal of Theory and Practice in Education, 5(2), 244-260.

Senemoglu, N. (2011). Development, learning and teaching: From theory to application. Ankara: Pegem Academy.

Shkedi, A. (1998). Teachers' attitudes towards research: A challenge for qualitative researchers. Qualitative Studies In Education, 11(4), 559-577. https://doi.org/10.1080/095183998236467

Topkaya, Y. (2016). The effect of teaching practice lessons on social studies teachers' self-efficacy perceptions. Anthropologist, 23(1-2), 236-244.

Yasar, S. (2006). Contemporary understanding of science. Eskisehir: Anadolu University Open Education Faculty Publications.

Yavuz, M. (2009). An analysis of thought of teachers and principals on educational research. Selcuk University Ahmet Kelesoglu Education Faculty Journal, 27, 143-158.

Yıldırım, A., İlhan, N., Sekerci, A. R., \& Sozbilir, M. (2014). Science teachers' level of following, understanding and using of educational researches: the example of Erzurum and Erzincan. Kastamonu Education Journal, 22(1), 81-100.

\section{Copyrights}

Copyright for this article is retained by the author(s), with first publication rights granted to the journal.

This is an open-access article distributed under the terms and conditions of the Creative Commons Attribution license which permits unrestricted use, distribution, and reproduction in any medium, provided the original work is properly cited. 